\title{
PENGARUH PEMBERIAN ANGKAK (Red Yeast Rice) TERHADAP KADAR KOLESTEROL TOTAL DAN TRIGLISERIDA PADA WANITA PENDERITA HIPERLIPIDEMIA
}

\author{
Balgis, Binar Panunggal") \\ Program Studi Ilmu Gizi Fakultas Kedokteran Universitas Diponegoro \\ J1.Dr.Sutomo No.18, Semarang, Telp (024) 8453708, Email : gizifk@ undip.ac.id
}

\begin{abstract}
Background : Hyperlipidemia have been shown to be one of the factors associated with cardiovascular disease. $R Y R$ contains of Monacolin $K$, which is a secondary metabolite that can obstruct cholesterol synthesis by blocking $H M G-C o A$ reductase enzyme performance. This study aimed to determine the effect of RYR on serum total cholesterol level and triglyceride level in women with hyperlipidemia.

Methods : This research was true experimental study with control group pre-test post-test design. Subject were women with serum total cholesterol level $\geq 200 \mathrm{mg} / \mathrm{dl}$ and or triglyceride level $\geq 150 \mathrm{mg} / \mathrm{dl}$, classified into 2 groups, treatment group consuming 4,8 g RYR/day and control group consuming placebo. RYR was consumed during 14 days. Blood was collected after an overnight fast. Serum total cholesterol level was measured with CHOD-PAP method and serum triglyceride was measured with GPO-PAP method. Shapiro Wilk was used to analyze normality of the data. The statistical analyzes include dependent t-test, Wilcoxon, independent t-test and Mann Whitney.

Result : Mean of cholesterol level and triglyceride level before intervention treatment group is 227,52 mg/dl and $166,57 \mathrm{mg} / \mathrm{dl}$. Mean of cholesterol level and triglyceride level after intervention treatment group is $234.31 \mathrm{mg} / \mathrm{dl}$ and $123.36 \mathrm{mg} / \mathrm{dl}$. There was no effect of consumption 4,8 g/day of $R Y R$ on Cholesterol level $(p=0,370)$ and triglyceride level $(p=0,099)$. There was no difference of cholesterol level $(p=0,442)$ and triglyceride level $(p=0.447)$ between control and treatment groups.

Conclusion : Consumption of RYR had no effect on Cholesterol level and triglyceride level in woman with hyperlipidemia. There was no difference of total cholesterol level and triglyceride level between control and treatment groups.
\end{abstract}

Keyword : Red Yeast Rice; total cholesterol; triglyceride; hyperlipidemia.

\begin{abstract}
ABSTRAK
Latar Belakang : Hiperlipidemia merupakan salah satu faktor risiko terjadinya penyakit jantung dan pembuluh darah. Angkak mengandung Monakolin K, yaitu metabolit sekunder yang dapat menghambat kerja enzim HMGKoA reduktase sehingga menghambat sintesis kolesterol. Penelitian ini bertujuan untuk mengetahui pengaruh pemberian angkak (Red Yeast Rice) terhadap kadar kolesterol total dan trigliserida pada wanita penderita hiperlipidemia.
\end{abstract}

Metode : Jenis penelitian adalah true experiment dengan rancangan control group pre test - post test. Subjek adalah 38 wanita hiperlipidemia dengan kadar kolesterol total $\geq 200 \mathrm{mg} /$ dl dan atau kadar trigliserida $\geq 150 \mathrm{mg} / \mathrm{dl}$, kelompok perlakuan mendapat 4.8 g/hari angkak dan kelompok kontrol mendapat plasebo. Intervensi dilakukan selama 14 hari. Metode CHOD-PAP digunakan untuk menganalisis kadar kolesterol total dan metode GPO-PAP digunakan untuk menganalisis kadar trigliserida, darah diambil setelah subyek berpuasa selama 10 jam. Uji normalitas menggunakan Shapiro Wilk. Analisis statistik menggunakan uji dependent t-test, Wilcoxon, independent t-test dan Mann Whitney.

Hasil : Rerata kadar kolesterol total dan trigliserida sebelum intervensi kelompok perlakuan berturut-turut yaitu 227,52 $\mathrm{mg} / \mathrm{dl}$ dan 166,57 $\mathrm{mg} / \mathrm{dl}$. Rerata kadar kolesterol total dan trigliserida setelah intervensi kelompok perlakuan berturut-turut yaitu $234.31 \mathrm{mg} / \mathrm{dl}$ dan $123.36 \mathrm{mg} / \mathrm{dl}$. Konsumsi angkak dengan dosis $4.8 \mathrm{~g} / \mathrm{hari}$ tidak berpengaruh terhadap kadar kolesterol total $(p=0.370)$ dan trigliserida $(p=0.099)$. Tidak ada perbedaan kadar kolesterol total $(p=0.442)$ dan trigliserida $(p=0.447)$ antara kelompok kontrol dan kelompok perlakuan.

Kesimpulan : Konsumsi angkak tidak berpengaruh terhadap kadar kolesterol total dan trigliserida pada wanita penderita hiperlipidemia. Tidak terdapat perbedaan kadar kolesterol total dan trigliserida antara kelompok kontrol dan perlakuan.

Kata kunci : angkak; kolesterol total; trigliserida; hiperlipidemia

\section{PENDAHULUAN}

Hiperlipidemia merupakan kondisi dimana kadar kolesterol dan atau trigliserida dalam darah meningkat di atas batas normal, hal ini merupakan salah satu faktor risiko terjadinya aterosklerosis dan penyakit arteri koroner dan dapat berkembang menjadi penyakit jantung dan pembuluh darah. ${ }^{1}$ Berdasarkan Profil Kesehatan Provinsi Jawa

${ }^{*}$ Penulis Penanggungjawab 
Tengah tahun 2011 penyakit jantung dan pembuluh darah merupakan kasus tertinggi yaitu sebesar $880.193(62,43 \%)$ dari total 1.409 .857 kasus penyakit tidak menular. ${ }^{2}$ Rekapitulasi data kesakitan tahun 2012 Dinas Kesehatan Kota Semarang melaporkan terdapat 8.462 kasus penyakit jantung dan pembuluh darah dengan rentang umur 15-64 tahun. ${ }^{3}$

Asupan merupakan salah satu faktor yang mempengaruhi kadar kolesterol dan trigliserida. Peningkatan konsumsi kolesterol sebanyak 100 $\mathrm{mg} /$ hari dapat meningkatkan kolesterol total sebanyak 2-3 mg/dl, sebaliknya penurunan konsumsi kolesterol sebanyak $100 \mathrm{mg}$ menyebabkan penurunan $\pm 0,13 \mathrm{mmol} / \mathrm{L}$ kolesterol dalam darah. Diet tinggi karbohidrat $>60 \%$ dari kebutuhan energi dapat mempengaruhi peningkatan kadar trigliserida darah. Selain karbohidrat, trigliserida juga dapat disintesis dari protein. Banyak asam amino dapat diubah menjadi asetil-KoA dan kemudian dapat disintesis menjadi trigliserida. Oleh karena itu bila seseorang mengonsumsi protein dalam makanan melebihi jumlah protein yang dapat digunakan jaringannya, sejumlah besar kelebihan ini akan disimpan sebagai lemak. Keadaan ini dapat berpengaruh pada proses biosintesis kolesterol. Sintesis kolesterol dipengaruhi oleh beberapa faktor, salah satunya penurunan aktivitas HMG KoA reduktase yang dapat menurunkan sintesis kolesterol. ${ }^{4,5}$

Angkak merupakan produk fermentasi beras oleh kapang Monascus Purpureus. ${ }^{6}$ Dalam 2,4 gram angkak terdapat 9,6 mg Monakolin K. ${ }^{7}$ Proses biosintesis kolesterol dapat dihambat oleh monakolin $\mathrm{K}$, dengan cara menghambat enzim HMG-KoA reduktase yang mengontrol jalur biosintesis kolesterol dalam hati, menghambat pembentukan mevalonat sehingga pembentukan kolesterol akan menurun. ${ }^{6,8}$

Sebuah penelitian di Cina tahun 1997 pada 324 orang dewasa hiperkolesterolemia menunjukkan bahwa pemberian angkak 1,2 gram/hari dalam bentuk kapsul selama 8 minggu terjadi penurunan total kolestrol sebesar $22,7 \%$ dan trigliserida $34,1 \% .^{9}$ Penelitian tahun 1999 pada 83 penduduk dewasa Amerika hiperlipidemia dengan diet terkontrol yaitu $30 \%$ energi berasal dari lemak, $<10 \%$ lemak jenuh, dan $<300 \mathrm{mg}$ kolesterol setiap harinya. Pemberian 2,4 gram angkak perhari selama 8 minggu menurunkan total kolesterol dan trigliserida berturut-turut yaitu sebesar $17 \%$ dan $16 \%$ dari nilai awal. ${ }^{10}$

Penelitian lainnya di Taiwan tahun 2005 pada 79 pasien menunjukkan bahwa konsumsi angkak dalam bentuk kapsul dengan dosis $600 \mathrm{mg}$ yang diberikan sehari dua kali selama 8 minggu secara signifikan dapat menurunkan total kolesterol 280,6 mg/dl menjadi 219,3 mg/dl $(21,5 \%)$ dan trigliserida $129,2 \mathrm{mg} / \mathrm{dl}$ menjadi 107,9 $\mathrm{mg} / \mathrm{dl} \quad(15,8 \%) .{ }^{11} \quad$ Penelitian di Indonesia menggunakan 42 ekor tikus percobaan galur sprague dawley yang telah dinaikkan kolesterolnya, menunjukkan bahwa pemberian 0,01 gram angkak selama 21 hari dapat menurunkan kadar kolesterol total sebesar $23,45 \% .^{12}$

Penelitian ini bertujuan untuk mengetahui pengaruh pemberian angkak terhadap kadar kolesterol total dan trigliserida pada wanita penderita hiperlipidemia.

\section{METODE}

Penelitian ini merupakan penelitian true experiment dengan rancangan control group pre test - post test. Variabel bebas dalam penelitian ini adalah pemberian angkak, sementara variabel terikat adalah kadar kolesterol total dan kadar trigliserida penderita hiperlipidemia.

Ethical Clearance adalah bentuk persetujuan bahwa secara etik penelitian ini dapat dilakukan pada manusia. Oleh karena penelitian ini bersifat eksperimental yaitu memberikan intervensi khusus pada kelompok perlakuan dan kontrol, oleh karena itu penelitian ini dilaksanakan setelah mendapat persetujuan dari Komite Etik, Fakultas Kedokteran Universitas Diponegoro. Pengambilan data sampel termasuk pemeriksaan darah dilakukan setelah mendapat persetujuan dari subjek dengan mengisi informed consent. Keterangan tentang untung dan ruginya mengikuti penelitian, serta efek samping dari intervensi dijelaskan kepada subjek oleh peneliti. Semua informasi dan data dari penelitian ini hanya dipakai untuk keperluan ilmiah dan kode maupun identitas subjek sangat dirahasiakan untuk umum.

Subjek penelitian merupakan karyawati kantor Badan Pusat Statistik Provinsi Jawa Tengah, karyawati kantor Badan Perencanaan Pembangunan Kota Semarang, karyawati kantor Badan Pusat Perijinan Terpadu Kota Semarang, dan karyawati yayasan Pangudi Luhur Semarang. Kriteria inklusi penelitian ini adalah memiliki kadar kolesterol total $\geq 200 \mathrm{mg} / \mathrm{dl}$ dan atau kadar trigliserida $\geq 150 \mathrm{mg} / \mathrm{dl}$, belum mengalami menopause, tidak sedang mengonsumsi obat antihiperlipidemia selama penelitian, tidak dalam keadaan sakit atau dalam perawatan dokter berkaitan dengan penyakit jantung koroner, 
diabetes melitus, hipertensi, gagal ginjal, dan penyakit kronik lainnya, dan tidak sedang hamil atau menyusui. Beberapa subjek memiliki kadar kolesterol $\leq 200 \mathrm{mg} / \mathrm{dl}$ dan trigliserida $\leq 150 \mathrm{mg} / \mathrm{dl}$ hal ini dikarenakan terbatasnya jumlah subjek yang memenuhi kriteria.

Perhitungan subjek penelitian menggunakan rumus uji hipotesis terhadap rerata dua populasi independen dan dibutuhkan sebanyak 38 subjek. Penentuan subjek penelitian menggunakan metode consecutive sampling. Sebanyak 102 orang bersedia diambil darahnya untuk proses skrining awal dan diperoleh sebanyak 40 subjek yang memenuhi kriteria inklusi, kemudian dilakukan simple randomization dan terpilih 38 subjek untuk menjadi subjek penelitian. Subjek dibagi menjadi 2 kelompok dengan metode simple randomization, yang terdiri atas kelompok kontrol dan kelompok perlakuan, masing-masing kelompok terdiri dari 19 subjek. Kelompok perlakuan mendapatkan angkak sebanyak 4,8 gram/hari dan kelompok kontrol mendapatkan plasebo yang terbuat dari beras sangrai.

Pemberian angkak dan plasebo dilakukan selama 14 hari. Asupan makan sehari-hari, pada kelompok kontrol dan kelompok perlakuan tidak dikontrol. Pencatatan makan dilakukan sebelum dan selama intervensi. Kepatuhan subjek mengonsumsi angkak dan plasebo dicatat dengan menggunakan formulir kepatuhan. Cara membuat filtrat angkak yaitu 4,8 g angkak dipanaskan dengan air 200cc, kemudian disaring dipisahkan dengan ampasnya.

Kadar kolesterol total dianalisis dengan pemeriksaan laboratorium menggunakan metode CHOD-PAP sedangkan kadar trigliserida dianalisis dengan menggunakan metode GPO-PAP. Sampel darah diambil oleh petugas laboratorium setelah subjek berpuasa selama \pm 10 jam. Data asupan makan subjek dianalisis menggunakan program nutrisurvey.

Untuk menguji kenormalan data menggunakan uji Shapiro-Wilk. Perbedaan kadar kolesterol total sebelum dan sesudah intervensi menggunakan dependent t-test dan perbedaan kadar trigliserida sebelum dan sesudah intervensi dengan menggunakan uji Wilcoxon. Perbedaan pengaruh perlakuan kedua kelompok dianalisis dengan menggunakan uji independent $t$-test untuk data normal dan uji Mann Whitney untuk data yang tidak normal.

\section{HASIL PENELITIAN \\ Karakteristik Subjek}

Karakteristik subjek yang terdiri dari gambaran umur dan status gizi disajikan dalam tabel 1 .

Tabel 1. Karakteristik subjek

\begin{tabular}{|c|c|c|c|c|c|c|c|}
\hline \multirow{2}{*}{ Variabel } & \multicolumn{4}{|c|}{$\begin{array}{c}\text { Perlakuan } \\
(n=19)\end{array}$} & \multicolumn{2}{|c|}{$\begin{array}{c}\text { Kontrol } \\
(n=19)\end{array}$} & \multirow{2}{*}{$\mathbf{p}$} \\
\hline & Mean \pm SD & $\mathrm{n}$ & $\%$ & Mean \pm SD & $\mathrm{n}$ & $\%$ & \\
\hline \multicolumn{8}{|l|}{ Umur } \\
\hline 28-37 & $4528+636$ & 3 & $7,9 \%$ & $4281+720$ & 4 & $10,5 \%$ & 0 273* \\
\hline $38-47$ & $43,28 \pm 6,36$ & 9 & $23,7 \%$ & $42,81 \pm /, 29$ & 8 & $21,1 \%$ & $0,2 / 3^{*}$ \\
\hline 48-57 & & 7 & $18,4 \%$ & & 7 & $18,4 \%$ & \\
\hline \multicolumn{8}{|l|}{ Status Gizi } \\
\hline Normal $\left(18,5-22,9 \mathrm{~kg} / \mathrm{m}^{2}\right)$ & & 2 & $5,3 \%$ & & 8 & $21,1 \%$ & \\
\hline $\begin{array}{l}\text { Overweight }(23-24,9 \\
\left.\mathrm{kg} / \mathrm{m}^{2}\right)\end{array}$ & $27,62 \pm 4,42$ & 4 & $10,5 \%$ & $23,90 \pm 2,88$ & 5 & $13,2 \%$ & $0,011 *$ \\
\hline Obesitas (>25 kg/m²) & & $\begin{array}{l}1 \\
3\end{array}$ & $34,2 \%$ & & 6 & $15,8 \%$ & \\
\hline Kolesterol total awal & $\begin{array}{l}227,52 \pm 28.5 \\
8\end{array}$ & & & $\begin{array}{c}226,68 \pm 35,7 \\
8\end{array}$ & & & $0,937 *$ \\
\hline Trigliserida awal & $\begin{array}{c}166,57 \pm 77,6 \\
4\end{array}$ & & & $\begin{array}{c}126,47 \pm 51,0 \\
4\end{array}$ & & & $\begin{array}{c}0,015^{*} \\
*\end{array}$ \\
\hline
\end{tabular}

* Uji beda independent t-test

**Mann Whitney 
Sebagian besar subjek dalam penelitian ini berada pada kelompok umur 38-47 tahun $(44,8 \%)$, sebagian besar memiliki kategori status gizi obesitas pada kelompok perlakuan $(34,2 \%)$ dan status gizi normal pada kelompok kontrol $(21,1 \%)$. Hasil uji t-test menunjukkan tidak terdapat perbedaan umur antara kedua kelompok ( $p>0,05)$. Terdapat perbedaan status gizi antara kedua kelompok $(\mathrm{p}<0,05)$. Tidak terdapat perbedaan rerata kadar kolesterol total awal antara kelompok perlakuan dan kontrol $(\mathrm{p}>0.05)$. Terdapat perbedaan kadar trigliserida awal antara kelompok perlakuan dan kelompok kontrol $(\mathrm{p}<0.05)$

Asupan energi, protein, lemak, karbohidrat, kolesterol dan serat kelompok perlakuan dan kontrol

Tabel 2 . Asupan energi, protein, lemak, karbohidrat, kolesterol dan serat kelompok perlakuan dan kontrol

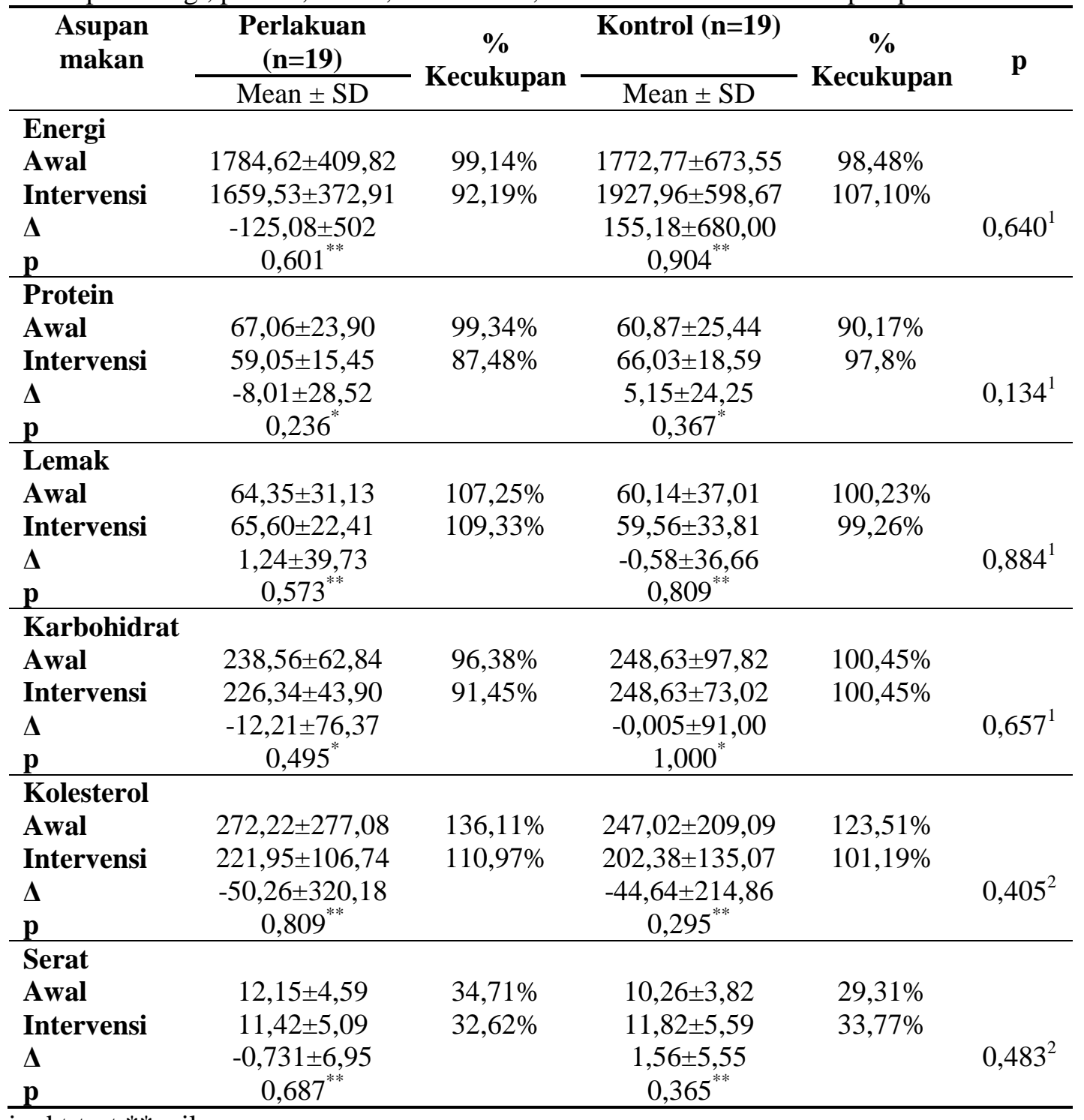

* paired t-test ** wilcoxon

1 Uji beda Independent T-Test 2 Uji beda Mann Whitney

$\%$ kecukupan berdasarkan AKG 2004 dan nutrition therapy for hyperlipidemia

Tidak terdapat perbedaan rerata asupan energi, protein, lemak, karbohidrat, kolesterol dan serat sebelum dan selama intervensi baik pada kelompok kontrol maupun kelompok perlakuan $(p>0.05)$. Tidak terdapat perbedaan perubahan asupan energi, protein lemak, karbohidrat, kolesterol dan serat antara kelompok perlakuan dan kelompok kontrol ( $p>0,05)$.

Kepatuhan konsumsi angkak pada kelompok perlakuan

Selama penelitian kelompok perlakuan mendapat intervensi berupa angkak sebanyak $(4,8$ 
g). Pada kelompok perlakuan, terdapat satu orang subjek tidak mengonsumsi angkak selama 2 hari dan satu orang subjek menyisakan $25 \%$ selama 4 hari.

\section{Pengaruh konsumsi angkak terhadap kadar kolesterol total dan trigliserida}

Tabel 3. Pengaruh konsumsi angkak terhadap kadar kolesterol total dan trigliserida

\begin{tabular}{lccc}
\hline \multirow{2}{*}{ Variabel } & Perlakuan $(\mathbf{n}=\mathbf{1 9})$ & Kontrol $(\mathbf{n}=\mathbf{1 9})$ & \multirow{2}{*}{$\mathbf{p}^{\mathbf{1}}$} \\
\cline { 2 - 3 } & Mean $\mathbf{\text { SD }}$ & Mean $\mathbf{\text { SD }}$ & \\
Kolesterol total (mg/dl) & & & \\
Awal & $227,52 \pm 28,58$ & $226,68 \pm 35,78$ & \\
Akhir & $234,31 \pm 37,64$ & $225,47 \pm 35,40$ & \\
$\boldsymbol{\Delta}$ & $6,78 \pm 32,20$ & $-1,21 \pm 31,26$ & 0,442 \\
$\mathbf{P}$ & $0,370^{*}$ & $0,868^{*}$ & \\
\hline Trigliserida (mg/dl) & & & \\
Awal & $166,57 \pm 77,64$ & $126,47 \pm 51,04$ & \\
Akhir & $151,84 \pm 72,27$ & $123,36 \pm 81,33$ & \\
$\boldsymbol{\Delta}$ & $-14,7 \pm 46,41$ & $-3,10 \pm 46,84$ & 0,447 \\
$\mathbf{P}$ & $0,099^{* *}$ & $0,573^{* *}$ & \\
\hline
\end{tabular}

*Uji dependent t-test

**Uji Wilcoxon

1 Uji beda Independent T-Test

Pada akhir penelitian didapatkan bahwa tidak terdapat perubahan rerata kolesterol total dan trigliserida setelah diberi intervensi baik pada kelompok kontrol maupun kelompok perlakuan $(\mathrm{p}>0,05)$. Tidak ada pengaruh konsumsi angkak terhadap kadar kolesterol total dan trigliserida.

Perbedaan rerata perubahan kadar kolesterol total dan trigliserida antar kedua kelompok dianalisis dengan uji Independent Samples T-Test, tidak terdapat perbedaan rerata perubahan kadar kolesterol total dan trigliserida antara kelompok perlakuan dan kelompok kontrol $(\mathrm{p}>0,05)$

\section{PEMBAHASAN}

Monakolin $\mathrm{K}$ berperan sebagai competitive inhibitor yang bersaing dengan HMG-KoA reduktase kemudian mereduksi sintesis kolesterol. ${ }^{13}$ Dalam 2,4 g angkak terdapat 9,6 mg Monakolin K. ${ }^{7}$ Bila monakolin K berikatan dengan HMG-KoA reduktase maka asam mevalonat yang merupakan senyawa dalam sintesis kolesterol tidak akan terbentuk, sehingga pembentukan kolesterol menjadi terhambat. ${ }^{12}$

Pada penelitian ini, pemberian angkak sebesar 4,8 g/hari selama 14 hari tidak memberikan pengaruh terhadap kadar kolesterol total dan trigliserida, hal ini ditunjukkan dengan hasil uji statistik tidak terdapat perbedaan kadar kolesterol total dan trigliserida sebelum dan setelah intervensi ( $p>0.05)$. Hasil uji statistik juga menunjukkan bahwa tidak terdapat perbedaan kadar kolesterol total dan trigliserida antara kelompok kontrol dan perlakuan. Hal ini berbeda dengan penelitian yang telah dilakukan di Taiwan pada 79 pasien yang menunjukkan bahwa konsumsi angkak dalam bentuk kapsul dengan dosis $600 \mathrm{mg}$ yang diberikan dua kali sehari selama 8 minggu secara signifikan dapat menurunkan kolesterol total $280,6 \mathrm{mg} / \mathrm{dl}$ menjadi $219,3 \mathrm{mg} / \mathrm{dl}(21,5 \%)$ dan trigliserida 129,2 $\mathrm{mg} / \mathrm{dl}$ menjadi $107,9 \mathrm{mg} / \mathrm{dl}(15,8 \%) .{ }^{11}$

Molekul kolesterol dibentuk melalui serangkaian reaksi yang melibatkan sejumlah enzim, salah satunya adalah enzim HMG-KoA reduktase, enzim ini memiliki substrat alami yaitu HMG-KoA. HMG-KoA reduktase adalah enzim utama yang mendukung sintesis kolesterol di hati dengan cara berikatan dengan mengubah HMGKoA menjadi mevalonat, ketika Monakolin K hadir dengan konsentrasi lebih dari konsentrasi HMG-KoA , maka HMG-KoA reduktase akan lebih cenderung berikatan dengan Monakolin K. hal ini akan menyebabkan laju pembentukan mevalonat yang merupakan prekursor kolesterol dari HMG-KoA akan terhambat sehingga jumlah dan frekuensi sintesis kolesterol akan menurun. . $^{13,14,15}$

Stabilitas pigmen angkak dipengaruhi oleh beberapa hal yaitu suhu, lama pemanasan, sinar matahari, $\mathrm{pH}$, jenis penyimpanan, serta lama penyimpanan. Pada suhu $100^{\circ} \mathrm{C}$ pigmen warna merah angkak berubah menjadi merah kehitaman 
akibat kerusakan molekul pigmen dalam larutan. Pemanasan selama 2 jam dapat menurunkan kadar Monakolin K sebesar 55\%. Waktu penyinaran 24 jam menyebabkan degradasi pigmen angkak, sinar matahari sangat mempengaruhi pigmen angkak, intensitas pigmen akan mengalami penurunan sebanyak $\pm 20 \%$ setelah waktu kontak 6 jam dan $60 \%$ setelah 24 jam. Pigmen angkak paling stabil pada kondisi $\mathrm{pH}$ alkali dan akan mengalami penurunan pada kondisi asam. Kemasan yang paling baik menjaga stabilitas pigmen selama penyimpanan adalah polipropilen berlapis alumunium dan gelas. Penurunan kadar pigmen angkak sudah terjadi pada waktu penyimpanan 1 bulan. ${ }^{16,17}$ Dimungkinkan terjadi penurunan kadar dari angkak yang digunakan, sehingga pengaruh angkak terhadap kolesterol tidak terlihat.

Kadar kolesterol total dan trigliserida dipengaruhi oleh beberapa faktor salah satunya yaitu asupan. Asupan karbohidrat, protein dan lemak seluruh subjek tidak terdapat perbedaan antara sebelum dan selama intervensi. Rerata asupan serat kelompok perlakuan saat intervensi $(11.42 \mathrm{~g})$ mengalami penurunan dibandingkan dengan sebelum intervensi $(12.15 \mathrm{~g})$. Pada kelompok kontrol, rerata asupan serat mengalami peningkatan walaupun dalam jumlah yang kecil, yaitu $10.26 \mathrm{~g}$ menjadi $10.46 \mathrm{~g}$. Rerata asupan serat seluruh subjek penelitian yaitu $11.62 \mathrm{~g}$. Anjuran kecukupan serat harian yang direkomendasikan oleh American Dietetic Association (ADA) yaitu 20-35 g/hari atau berdasarkan Dietary Reference Intake (DRI) setara dengan $14 \mathrm{~g} / 1000 \mathrm{kkal}^{18}$

Rerata asupan serat subjek penelitian baik sebelum intervensi maupun saat intervensi masih tergolong rendah dan belum mencukupi kebutuhan yang dianjurkan. Asupan serat yang rendah merupakan salah satu penyebab tingginya kadar kolesterol. Konsumsi serat diketahui dapat meningkatkan ekskresi lemak melalui feses sebanyak 2-4 g/hari. Serat larut air berfungsi dalam memperlambat waktu pengosongan lambung, meningkatkan ketebalan lapisan intestinal yang berfungsi sebagai tempat absorpsi lipid, serta memberikan efek hipomotilitas untuk memperlambat proses pencernaan dan absorpsi zat gizi. $^{19}$

Serat larut air dapat menghambat absorpsi dan metabolisme asam empedu dengan cara mengikat asam empedu dan meningkatkan pengeluarannya melalui feses. Kemampuan serat untuk mengikat asam empedu mengakibatkan adanya peningkatan jumlah kolesterol yang digunakan untuk mensistesis asam empedu serta menurunnya jumlah kolesterol yang digunakan untuk mensintesis lipoprotein. Serat akan mengikat lemak sehingga penyerapan lemak akan terganggu. Serat akan mengikat asam empedu dan membentuk misel yang akan dikeluarkan melalui feses. ${ }^{20}$

Rata-rata peningkatan asupan kolesterol $100 \mathrm{mg} /$ hari dapat meningkatkan serum kolesterol $2-3 \mathrm{mg} / \mathrm{dl}^{5}$ Rerata asupan kolesterol seluruh subjek yaitu $212.17 \mathrm{mg}$, hal ini menunjukkan bahwa asupan kolesterol subjek masih melebihi anjuran (>200mg), sehingga dimungkinkan hal ini juga mempengaruhi kadar kolesterol subjek setelah diberi intervensi.

Untuk menurunkan kadar kolesterol total dan trigliserida, selain mengkonsumsi angkak juga perlu didukung dengan perubahan pola hidup diantaranya dengan cara mengurangi asupan kolesterol dan meningkatkan asupan serat.

\section{KETERBATASAN PENELITIAN}

Keterbatasan penelitian ini adalah tidak dilakukan uji kandungan Monakolin $\mathrm{K}$ pada angkak yang digunakan.

\section{KESIMPULAN}

Pemberian angkak dengan dosis $4.8 \mathrm{~g}$ per hari selama 14 hari tidak berpengaruh terhadap kadar kolesterol total dan trigliserida pada wanita dengan hiperlipidemia. Tidak ada perbedaan kadar kolesterol total dan trigliserida antara kelompok kontrol dan perlakuan.

\section{SARAN}

Diperlukan uji laboratorium untuk mengetahui besar kandungan Monakolin $\mathrm{K}$ di dalam angkak. Serta diperlukan penelitian lebih lanjut dengan waktu pemberian yang lebih panjang.

\section{DAFTAR PUSTAKA}

1. Carolt TB. Penyakit Aterosklerotik koroner. In : Sylvia A. Price, Lorraine M. Wilson. Patofisiologi Konsep Klinis Proses-Proses Penyakit. Edisi 6. Jakarta: Penerbit buku kedokteran EGC; 2006.p.576-612

2. Profil Kesehatan Provinsi Jawa Tengah 2011 [serial online] [cited 2013 April 18] Available from: URL: http://jateng.bps.go.id/index.php

3. Laporan Dinas Kesehatan Kota Semarang. Rekapitulasi Data Kesakitan Tahun 2012

4. Kathleen MB, Mayes PA. Sintesis, Transpor dan Ekskresi Kolesterol. In: Murray RK, Granner DK, Mayes PA, Rodwell VW, editors. Biokimia Harper. Edisi 27. Jakarta: Penerbit Buku Kedokteran EGC; 2009.p.239-49 
5. Jingbo H, Jiri F. The impact of dietary changes and dietary supplements on lipid profile. Canadian Journal of Cardiology. [serial online] 2011; Vol 27:488-505. [cited 2013 April 8] Available from: URL:

http://www.ncbi.nlm.nih.gov/pubmed/21801978

6. Ernawati K, Sri A, Novik N. Karakteristik pigmen dan kadar lovastatin beberapa isolate monascus purpureus. [serial online] 2005;Vol 6: No.4:245-47 [cited 2013 March 20] Available from: URL: http://biodiversitas.mipa.uns.ac.id/D/D0604/D060 406.pdf

7. Melanie J, Peter JHJ. Red yeast rice : a new hypolipidemic drug. Life Sciences. [serial online] 2004:2675-683. [cited 2013 April 3] Available from: URL:

http://www.sciencedirect.com/science/article/pii/S 0024320504000840

8. Zhen YC, Ka YM, Yintong L. Role and classification of cholesterol lowering functional foods. Journal of Functional Foods. [serial online] 2011; Vol 3:61-9. [cited 2013 April 8] Available from: URL:

http://www.sciencedirect.com/science/article/pii/S 1756464611000089

9. Junxian W, Zongliang L, Jiamin C. Multicenter clinical trial of the serum lipid lowering effects of a monascus purpureus (Red Yeast) Rice preparation from traditional Chinese medicine. [serial online] 1997; Vol 58:No. 12 [cited 2013 April 29] Available from: URL:

http://www.sciencedirect.com/science/article/pii/S 0011393X9780063X

10. Heber D, Ian Y, Judith MA, et al. Cholesterollowering effects of a proprietary Chinese red-yeast rice dietary supplement. The American Journal of Clinical Nutrition. [serial online] 1999;69:231-6. [cited 2013 April 2] Availabe from: URL: ajcn.nutrition.org

11. Cheng-chieh L, Tsai CL, Ming ML. Efficacy and safety of Monascus purpureus went rice in subjects with hyperlipidemia. European Journal of Endocrinology [serial online] 2005;153:679-86. [cited 2013 February 19] Available from: URL: http://www.ncbi.nlm.nih.gov/pubmed/16260426

12. Ernawati K, Yety K, Novik N. Pemanfaatan isolat local Monascus purpureus untuk menurunkan kolesterol darah pada tikus putih galur Sprague Dawley. [serial online] 2006;Vol 7: No.2:123-6 [cited 2013 February 19] Available from: URL: http://biodiversitas.mipa.uns.ac.id/D/D0702/D070 206.pdf

13. C. Arunachalam, D. Narmadhapriya. Monascus fermented rice and its beneficial aspects: a new review. Research Department of Microbiology Sri Sankara Arts and Science College. [serial online] 2011 [cited 2013 March 20]; Vol 4. Available from:

URL:
14. Hasim D. Optimizing angkak pigments and lovastatin production by Monascus purpureus. Hayati Journal of Biosciences. [serial onine] 2008 [cited 2013 February 13] Vol 15:No.2:61-6 Available from: URL:http://ilkom.journal.ipb.ac.id/index.php/hayat i/article/viewArticle/271

15. Tigor N, Linar ZU. Model fermentasi lovastatin. Akta Kimindo. [serial online] 2006 [cited 2013 May 5] Vol 1:No.2:99-104. Available from: URL:http://www.analitik.chem.its.ac.id/attachment s/-01_07-\%20Tigor\%20Nauli.pdf

16. Betty SLJ, K. Dharma M, Srikandi F. Produksi konsentrat dan bubuk pigmen angkak dari Monascus Purpureus serta stabilitasnya selama penyimpanan. Buletin Teknologi dan industry pangan. [serial online] 1997 [cited 2013 September 15] Vol VIII:No 2. Available from: http://repository.ipb.ac.id/bitstream/handle/123456 789/41853/8-e.pdf

17. Danik DA. Peningkatan intensitas pigmen dan kadar lovastatin angkak oleh Monascus purpureus ko-kultur dengan khamir amilolitik indigenus. [serial online] 2011 [cited 2013 september 16]. Available from: http://repository.ipb.ac.id/handle/123456789/52 $\underline{877}$

18. Dreher ML. Dietary Fiber Overview. Indiana : Mead Johnson Nutritionals/Bristol-Myers Squibb Company, Evansville. 2001

19. Lisa Brown, Bernard Rosner, walter W, Frank M sacks. Cholesterol lowering effects of dietary fiber: a meta-analysis. [serial online] 1999 [cited 2013 September 1] 69:30-4. Available from: http://ajcn.nutrition.org/content/69/1/30.full.pdf+ht $\underline{\mathrm{ml}}$

20. Gropper SS, Smith JL, Groff JL. Advanced nutrition and human metabolism. 5th ed. United States of America: Wadsworth;2009.p.115-16 